\title{
Avifaunal diversity in two residential localities of Kolkata, India
}

\author{
Ramyani Chattopadhyay ${ }^{1, a^{*}}$,Sudeshna Ghoshal ${ }^{2, b}$ \\ ${ }^{1}$ Shri Shikshayatan College,11 Lord Sinha Road,Kolkata 700071,West Bengal, India \\ ${ }^{2}$ Vijaygarh Jyotish Ray College,8/2 Bijoygarh,Kolkata 700032,West Bengal, India \\ a chattopadhyayramyani@gmail.com, ${ }^{\text {b}}$ Sudeshnaghosalvjrc@gmail.com
}

\section{Keywords: Kolkata, Avifauna, Pollution}

\begin{abstract}
Avifauna in two different residential localities of Kolkata viz. Cossipore of North Kolkata and Dhakuria of South Kolkata was done in twelve months period from December, 2013 November, 2014 to get some idea about the present avian diversity of the city. Total forty eight species of birds belonging to twenty five families were identified from the two sites and recorded along with their abundance in this study. Fluctuations in abundance of bird fauna between the study areas were also recorded which may be attributed to the loss of proper habitat for foraging and nesting due to continuous urbanization and increased pollution rates.
\end{abstract}

\section{INTRODUCTION}

Kolkata, the capital city of West Bengal, is located on the east bank of the Hooghly River. It is the principal commercial, cultural and educational centre of Eastern India. Much of the city was originally a wetland [1] that was reclaimed over the decades to accommodate a burgeoning population and this process is continuously going on as the city is now becoming a megacity. With the advancement of development, megacity has now been expanding up to different sub urban areas and consequently it is facing serious anthropogenic problems related to its rapidly changing urbanization pattern like- reduction of its greenery and overloaded with pollution etc. So the study of biodiversity in a city like Kolkata is now becoming interesting. Because such apparent inhospitable environmental condition would be threatening to its biodiversity resources and this intense anthropogenic pressure may induce rapid negative impact on urban wildlife especially on its avian population because birds amongst other species provide a wide range of environmental and social functions to cities and urban dwellers[2,3,4].Birds are considered excellent bio-indicators of the effects urbanization has on ecosystem. Besides, birds are also identified as indicators of aquatic and terrestrial habitat quality, changes in landscape pattern, composition and function[5].Thus the study of avifaunal diversity of a region is very important to assess the impacts of environmental change on its biodiversity resources and this in turn may create a data base which eventually helps in monitoring biodiversity of said area and also be useful in future planning for environmental management. Keeping all these views in mind the present study is carried out in two different residential localities of Kolkata viz. Dhakuria at southern part, and Cossipore at northern sub-urban area, to gather some information about the avifaunal diversity of those areas as these regions have faced drastic landscape changes due to growing urbanization and this may, in turn, indeed affect the biodiversity resources; as habitat loss due to land use change and/or human interference is the most important and often cited reasons of loss of biodiversity[5]. Hence this study is of unique importance, focusing mainly on those birds that are now available there which in turn reveal the composition of a greater part of the ecological community present in those regions. 


\section{MATERIALS AND METHODS \\ Study area}

The study was conducted from December 2013 to November 2014 at two sites of Kolkata viz.Cossipore - at the north sub-urban region and, Dhakuria at southern region. The avifauna and their abundance were studied in both study sites and compared.

Kolkata city $\left(22^{0} 34^{\prime} \mathrm{N}\right.$ and $\left.88^{0} 24^{\prime} \mathrm{E}\right)[6]$ is located in eastern part of India and spread linearly along the banks of Hooghly River. The city is near sea level with an average elevation being 17 feet. The climate here is tropical wet and dry with summer monsoon, high humidity and well distributed rainfall. Annual mean temperature was recorded as $28.4^{0} \mathrm{C}$ while monthly mean temperatures range from $19^{\circ} \mathrm{C}-30^{\circ} \mathrm{C}$. The maximum rainfall is more than $300 \mathrm{~mm}$ occurs during the month of August and the average annual rainfall is about $1500 \mathrm{~mm}$, along with relative humidity varies between $47 \%$ and $83 \%$.[7]

Study area-1 Cossipore is situated near east bank of Hooghly River. It is an age old sub-urban residential/industrial area and now facing serious threats due to expansion of urbanization. Vegetation is classified here into natural and planted trees as well as shrubs. Considerable number of green spaces and water bodies are present. Besides, a number of small scale industries are also marking their presence by promoting pollution in this area.

Study area-2 Dhakuria is a totally urbanized area and it was initially developed for supporting the growing population of city Kolkata. Residential houses and public places are scattered here along with several natural and planted greeneries. Presence of a large artificial lake Rabindra Sarobar often called the breathing ground of Kolkata, contributes a major parts of maintaining the biodiversity of this region although both lake and its adjoining areas are now facing serious problems regarding pollution related to automobiles and anthropogenic interferences.

\section{METHOD}

The present study is a list of bird species that are usually found in those areas and it was carried out during December,2013 to November,2014, twice in each month from 7am-9am and $4 \mathrm{pm}-5.30 \mathrm{pm}$. Birds were counted by point counting and look and see methods by using field binocular and were identified with the help of taxonomic book[8].Observations were made by standing and sitting from a hiding place and recorded along with their abundance. On the basis of the frequency of sighting, the bird species were assigned categories of abundance: VC- Very Common (Seen very commonly in most of the visited areas); C Common(Seen commonly in the study areas); NR Not Rare (Seen many times but not common); R Rare(Seen only once or twice)[9].

\section{RESULT AND DISCUSSION}

A total of forty eight separate species of birds belonging to twenty five families were observed during the study period (December2013- November2014) from the two study sites of Kolkata (Table 1). The study reveals that species diversity in Dhakuria was (48 species) is higher than that of Cossipore (44 species) (Figure 3). In Cossipore, a total of 44 species of birds belonging to 25 families were recorded. While in Dhakuria, a total of 48 species of birds belonging to 25 families were found. Species richness in southern part of Kolkata is much higher than its northern part and it may be due to the presence of much green spaces there. Besides Rabindra sarobar provides excellent foraging and nesting sites for both water and terrestrial birds as this lake is surrounded by various trees and shurbs, although water pollution and human interference is now a serious problem here. 
Table I Avifauna observed in two areas of Kolkata along with abundance during study

\begin{tabular}{|c|c|c|c|c|c|}
\hline Sl No & Family & Common name & Scientific name & $\mathrm{C}$ & $\mathrm{D}$ \\
\hline \multirow[t]{4}{*}{1} & Sturnidae & Common Myna & Acridotheres tristis & $\mathrm{VC}$ & $\mathrm{VC}$ \\
\hline & & Asian Pied Starling & Gracupica contra & NR & $\mathrm{C}$ \\
\hline & & Jungle Myna & Acridotheres fuscus & $\mathrm{C}$ & $\mathrm{R}$ \\
\hline & & Grey Headed Starling & Sturnia erythropygia & $\mathrm{X}$ & $\mathrm{R}$ \\
\hline 2 & Passeridae & House sparrow & Passer domesticus & $\mathrm{VC}$ & $\mathrm{VC}$ \\
\hline \multirow[t]{4}{*}{3} & Columbidae & Spotted Dove & Streptopelia chinensis & $\mathrm{C}$ & $\mathrm{C}$ \\
\hline & & Oriental Turtle Dove & S. orientalis & $\mathrm{R}$ & $\mathrm{R}$ \\
\hline & & Rock Pigeon & Colomba livia & $\mathrm{C}$ & $\mathrm{C}$ \\
\hline & & Yellow Legged Green Pigeon & Treron phoenicopterus & $\mathrm{R}$ & $\mathrm{R}$ \\
\hline \multirow[t]{2}{*}{4} & Pycnonotidae & Red Whiskered bulbul & Pycnonotus jocosus & NR & $\mathrm{C}$ \\
\hline & & Red vented bulbul & Pycnonotus cafer & $\mathrm{VC}$ & $\mathrm{VC}$ \\
\hline \multirow[t]{2}{*}{5} & Alcedinidae & White breasted Kingfisher & Halcyon smyrnensis & $\mathrm{R}$ & $\mathrm{R}$ \\
\hline & & Common Kingfisher & Alcido atthis & $\mathrm{C}$ & $\mathrm{C}$ \\
\hline \multirow[t]{2}{*}{6} & Picidae & Black Rumped Flameback & Dinopium benghalense & $\mathrm{C}$ & $\mathrm{C}$ \\
\hline & & Fulvous Breasted Pied Woodpecker & Dendrocopos macei & $\mathrm{R}$ & NR \\
\hline \multirow[t]{2}{*}{7} & Psittacidae & Rose ringed parakeet & Psittacula krameri & $\mathrm{C}$ & $\mathrm{C}$ \\
\hline & & Plum headed Parakeet & P. cyanocephala & $\mathrm{X}$ & $\mathrm{R}$ \\
\hline \multirow[t]{3}{*}{8} & Cuculidae & Common Hawk cuckoo & Hierococcyx varius & $\mathrm{C}$ & $\mathrm{C}$ \\
\hline & & Asian koel & Eudynamys scolopaceus & $\mathrm{C}$ & $\mathrm{C}$ \\
\hline & & Greater Coucal & Centropus sinensis & $\mathrm{R}$ & $\mathrm{R}$ \\
\hline \multirow[t]{2}{*}{9} & Oriolidae & Black Hooded Oriole & Oriolus xanthornus & $\mathrm{C}$ & $\mathrm{C}$ \\
\hline & & Indian Golden Oriole & Oriolus kundoo & $\mathrm{X}$ & $\mathrm{R}$ \\
\hline 10 & Meropidae & Green bee eater & Merops orientalis & $\mathrm{R}$ & $\mathrm{R}$ \\
\hline \multirow[t]{2}{*}{11} & Capitonidae & Blue Throated Barbet & Megalaima asiatica & NR & NR \\
\hline & & Copper Smith Barbet & Megalaima haemacephala & $\mathrm{R}$ & NR \\
\hline 12 & Dicruridae & Black Drongo & Dicrurus macrocercus & $\mathrm{R}$ & $\mathrm{C}$ \\
\hline 13 & Cisticolidae & Common Tailorbird & Orthotomus sutorius & $\mathrm{VC}$ & $\mathrm{C}$ \\
\hline \multirow[t]{2}{*}{14} & Nectariniidae & Purple Sunbird & Cinnyris asiaticus & $\mathrm{C}$ & $\mathrm{R}$ \\
\hline & & Purple Rumped Sunbird & Leptocoma zeylonica & NR & NR \\
\hline \multirow[t]{4}{*}{15} & Ardeidae & Little Egret & Egretta garzetta & $\mathrm{R}$ & $\mathrm{C}$ \\
\hline & & Eastern Cattle Egret & Bubulcus coromandus & $\mathrm{C}$ & $\mathrm{VC}$ \\
\hline & & Indian Pond Heron & Ardeola grayii & $\mathrm{C}$ & $\mathrm{C}$ \\
\hline & & Black Crowned Night Heron & Nycticorax nycticorax & $\mathrm{R}$ & NR \\
\hline 16 & Phalacrocoracidae & Little Cormorant & Phalacrocorax niger & NR & $\mathrm{C}$ \\
\hline \multirow[t]{2}{*}{17} & Strigidae & Common Burn owl & Tyto alba & $\mathrm{R}$ & $\mathrm{R}$ \\
\hline & & Spotted Owlet & Atheme brama & $\mathrm{R}$ & $\mathrm{R}$ \\
\hline \multirow[t]{2}{*}{18} & Apodidae & Little Swift & Apus affinis & $\mathrm{C}$ & $\mathrm{C}$ \\
\hline & & Asian Palm Swift & Cypsiurus balasiensis & NR & NR \\
\hline \multirow[t]{2}{*}{19} & Accipitridae & Black Kite & Milvus migrans & $\mathrm{C}$ & $\mathrm{C}$ \\
\hline & & Shikra & Accipiter badius & $\mathrm{X}$ & $\mathrm{R}$ \\
\hline 20 & Muscicapidae & Oriental magpie robin & Copsychus saularis & $\mathrm{VC}$ & $\mathrm{VC}$ \\
\hline \multirow[t]{3}{*}{21} & Corvidae & House crow & Corvus splendens & $\mathrm{VC}$ & $\mathrm{VC}$ \\
\hline & & Jungle crow & Corvus macrorhynchos & NR & $\mathrm{R}$ \\
\hline & & Rufous Treepie & Dendrocitta vagabunda & $\mathrm{R}$ & NR \\
\hline 22 & Rallidae & White breasted water hen & Amaurornis phoenicurus & $\mathrm{R}$ & $\mathrm{R}$ \\
\hline 23 & Timalidae & Jungle babbler & Turdoides striata & $\mathrm{R}$ & $\mathrm{C}$ \\
\hline 24 & Motacillidae & White Wagtail & Motacilla alba & $\mathrm{R}$ & $\mathrm{R}$ \\
\hline 25 & Lanidae & Brown Shrike & Lanius cristatus & $\mathrm{R}$ & $\mathrm{R}$ \\
\hline
\end{tabular}

$\mathrm{C}=$ Cossipore, $\mathrm{D}=$ Dhakuria

Regarding the relative abundance of bird species, Rare species were higher $(38 \%)$ in Cossipore, followed by Common (32\%), Not Rare (16\%) and Very Common (14\%) species. While in Dhakuria a different scenario in observed (Figure 2) especially with regards to rare bird species. Here Common species of birds were observed in higher magnitude (38\%) followed by Rare (35\%), Not Rare (15\%) and Very Common (13\%). A little variation is observed regarding the presence of 
Very Common and Not Rare bird species in the two study areas. So the highest number of species was common species of birds (38\%) in Dhakuria, while it was rare species (38\%) in Cossipore. This finding indicates that the habitat of the Cossipore may not be suitable for avifauna because it represents lower density of bird species and majority of birds belong to status "Rare". Generally urban air pollution can be regarded as one of reasons behind the reduction of the survival rate of both adult birds and nestlings[10] and Cossipore being an industrial area is also facing such problem[11,12].Besides landscape pattern of Cossipore is changing due to rapid urbanization. So the habitat quality may be low and unproductive there and this in turn, affect life pattern both nestling and adult birds.

The family-wise distribution of bird species at the two study sites is represented by using a histogram (Figure 1). This distribution shows that among twenty five families, species richness of twenty one families follow similar pattern in both the study-areas. Only representatives of four avian families' viz. Sturnidae, Psittacidae, Oriolidae, and Acciptiridae show higher appearance in Dhakuria site. This finding again correlates with earlier statement that South Kolkata is much more enriched with avian population. In Dhakuria the level of pollution is higher and mostly due to noise and automobiles[12] but within this area Rabindra Sarobar lake a green 'oasis' and, the biggest greenery patch of south Kolkata is present. Because of it residential area surrounding this lake also witnessed several birds which are not found elsewhere in Kolkata.

In both study sites whether it is the northern or in southern part of Kolkata house crow (Corvus splendens), common myna( Acridotheres tristis), house sparrow (Passer domesticus), red vented bulbul (Pycnonotus cafer), and oriental magpie robin( Copsychus saularis) are the most abundant species recorded during our study period.

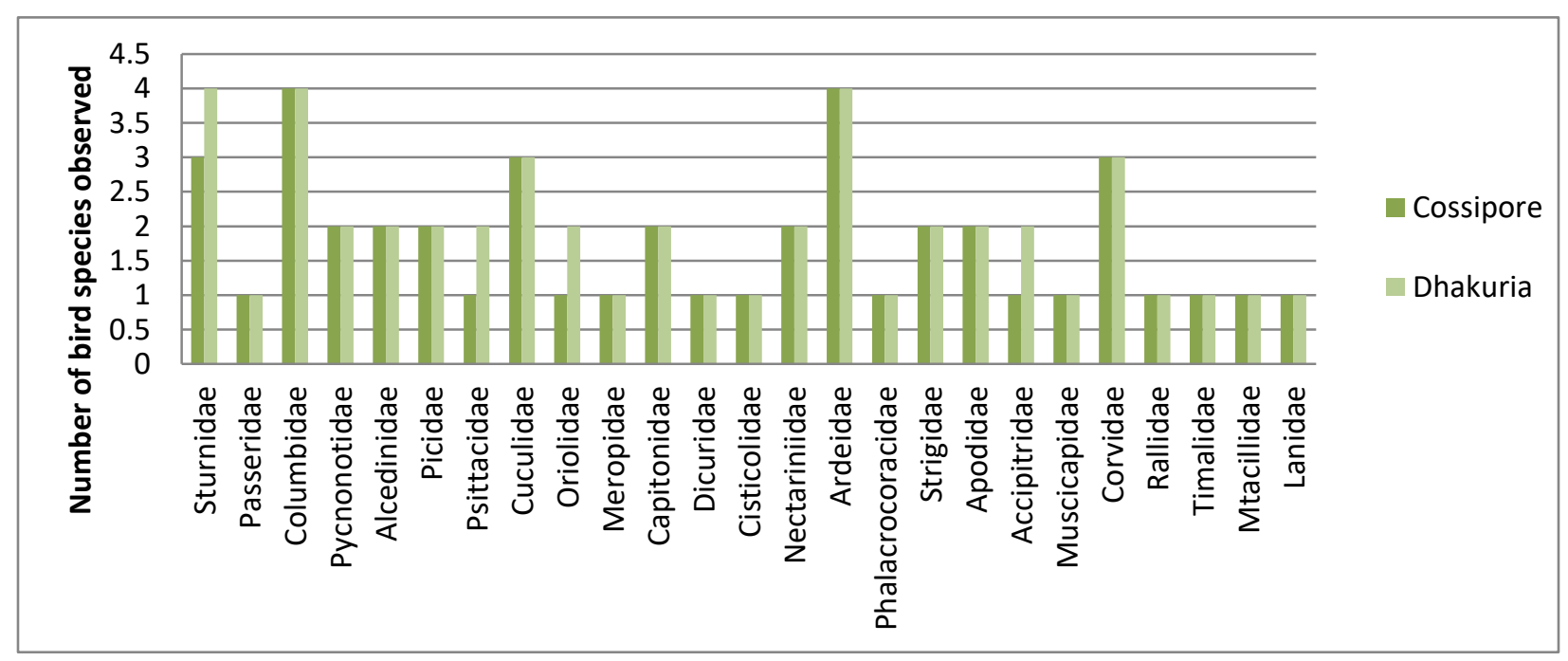

Figure 1: Comparative histogram showing Family wise distribution of bird species observed in two study area (Cossipore-North Kolkata, Dhakuria-South Kolkata).

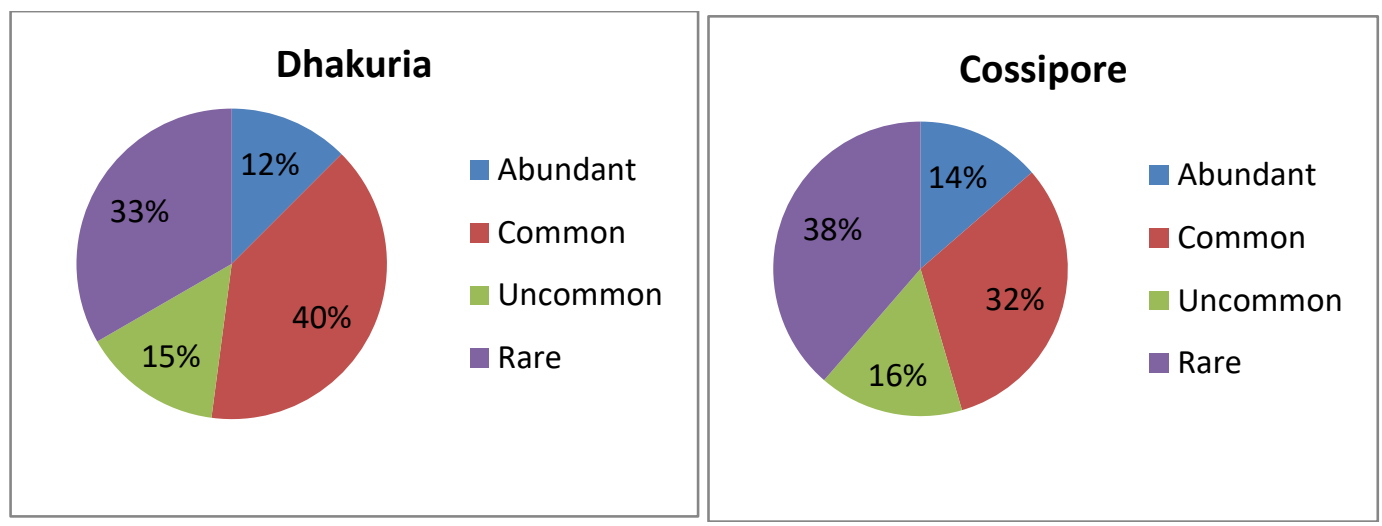

Figure 2: Comparative pie charts showing the number of bird species observed along two study area (Cossipore-North Kolkata, Dhakuria-South Kolkata) according to their abundance. 


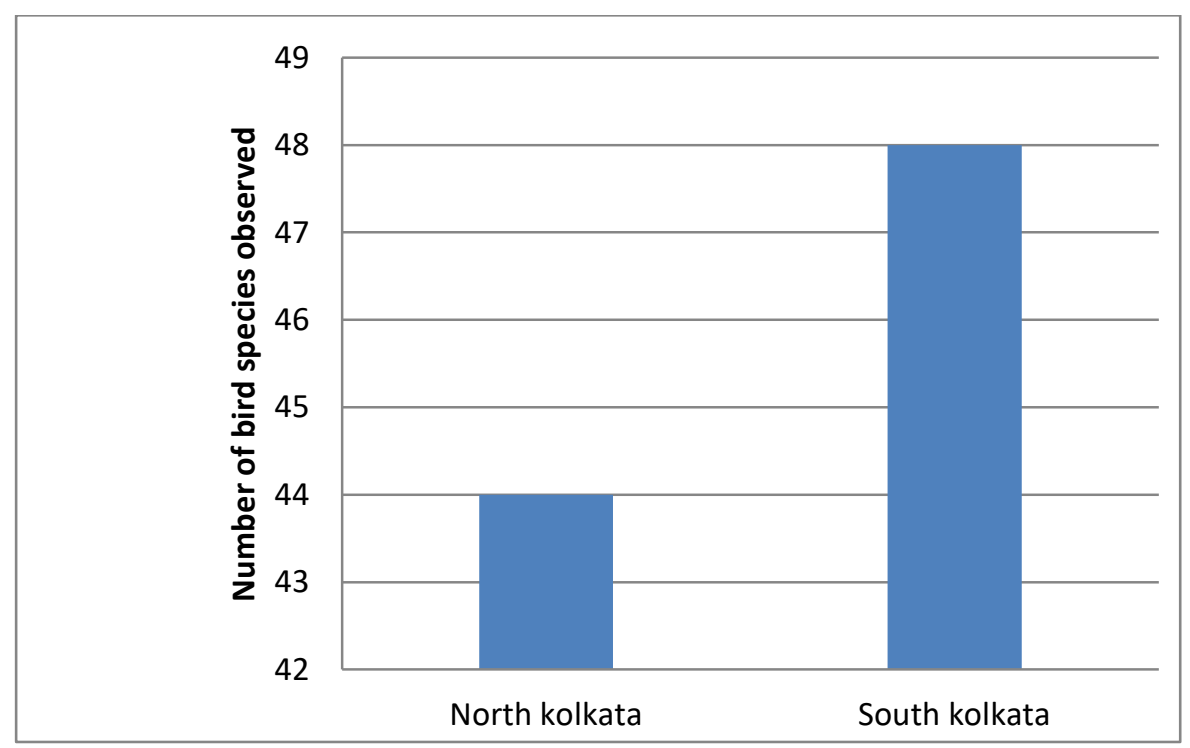

Figure 3: Histograms showing species richness of birds along two study sites (Cossipore-North Kolkata, Dhakuria-South Kolkata).

\section{CONCLUSION}

Our study sites are exclusively residential areas and are still urbanizing. A lot of human interferences are there, besides constructional activities, noise, pollution due to vehicles etc. are always making threat to the species of avifauna of this region. It could be the reason why species diversity is variable. Still these sites have supported significant number of avifauna particularly at the southern part of Kolkata (Dhakuria) showing the area may provide some potential habitats to the birds. Present observation provides a preliminary report and further survey with aim to study the landscape pattern in and around these areas with respect to bird fauna is required for better understanding of biodiversity resources here. Therefore, it is the need to monitor these areas systematically with a focused study on status, distribution and conservation of birds.

\section{References}

[1] Chatterjee, S. N. (2008). Water Resources, Conservation and Management. New Delhi: Atlantic Publishers and Distributors. p. 33. ISBN 81-269-0868-8.

[2] Heerwagen, J.H. and G. Orians. 1986. Adaptations to windowlessness: A study of the use of visual decor in windowed and windowless offices. Environment and Behavior 18(5):623-639.

[3] Costanza, R. \& Folke, C. in Nature's Services: Societal Dependence on Natural Ecosystems (ed. Daily, G.) 49-70 (Island, Washington DC, 1997).

[4] Sanesi, G. and Chiarello, F. (2006) Residents and urban green spaces: The case of

[5] Bari. Urban Forestry \& Urban Greening 4: 125-134

[6] Palmer, M.A., Bernhardt, E., Chornesky, E., Collins, S.,Dobson, A., Duke, C., Gold, B., Jacobson, R., Kingsland,S., Kranz, R., Mappin, M., Martinez, M.L., Micheli, F.,Morse, J., Pace, M., Pascual, M., Palumbi, S., Reichman, O.J.,Simons, A., Townsend, A. \& Turner, M. (2004) Ecology for a crowded planet. Science, 304, 1251-1252.

[7] "PIA01844: space radar image of Calcutta, West Bengal, India". NASA. 15 April 1999. Retrieved 15 January 2012

[8] Weatherbase entry for Kolkata

[9] Ali, Salim and Ripley, D. 1995. A pictorial guide to the birds of the Indian Subcontinent.Bombay Natural Histry Society and Oxford University Press, Mumbai. 
[10] Talmale S.S.. Limje M.E and Sambath S. Avian diversity of Singhori Wildlife Sanctuary, Raisen District,Madhya Pradesh. Biological Forum - An International Journal 4(2): 5261(2012)

[11]Dauwe T., Eens M., Naturwissenschaften 95 (2008) 969-973

[12] Tripathi DP, Dhar BB (2002)Environmental Polltion Research. A.P.H Publishing Corporation.

[13]CPCB, Central Pollution Control Board, New Delhi, (2009).http://www.cpcb.nic. in/bulletin /del/2009html. 